\title{
STRATEGY OF INDONESIA GOVERNMENT TO MANTAINS PALM OIL MARKET IN INDIA
}

\author{
Glory Yolanda Yahya, Desri Gunawan \\ Dosen Program Studi Hubungan Internasional Universitas Maritim Raja Ali Haji \\ Email: gloryyolanda@umrah.ac.id,gunawandesri@umrah.ac.id
}

\begin{abstract}
This study aims to determine the factors cause a decrease market share of Indonesia palm oil in India and its implications, and to know the Indonesia government's strategy maintains the palm oil market in India. The method used is descriptive analysis using theory of competitive adventage diamond model of Michael Porter and Development state theory. The scope of study between 2010 and 2015. The results showed that cause of the decline in the market share of Indonesia palm oil in India due to the application of duty Crude Palm Oil (CPO) is higher than its derivative products in Indonesia, Increased demand for Malaysia palm oil by India and development of palm oil industry in India. The implications of this decline include the loss of potential tax revenue and export volume of palm oil as well as disrupt the Indonesia palm oil industry. Strategy by the Indonesia government is implementing Crude Palm Oil (CPO) Supporting Fund (CSF), Indonesia Trade Promotion Center (ITPC) Chennai (India) and Palm Oil Industrial Cluster. Strategy Indonesia government maintains the palm oil market in India has shown a positive effect. Although some parts are not running perfectly. The government as a stimulant to increase competitiveness of Indonesia palm oil is felt has done its job as it should. Futhermore, this strategy can be continued with evaluation and continuous improvement.
\end{abstract}

Keyword: India, Export Palm Oil, Competitive Advantage, Development State, Crude Palm Oil (CPO) Supporting Fund (CSF). Indonesian Trade Promotion Center (ITPC) Chennai, Oil Palm Industry Cluster (KIKS)

\section{INTRODUCTION}

India is the main destination of Indonesia palm oil export with total volume in 2010 attain 5,5 million ton from 17,58 million ton of total export with the value US \$4,57 billion. ${ }^{1}$ Palm oil is one of the main export commodity of Indonesia, where it is the biggest palm oil exporter by producing 27,31 million ton in 2010 and possesses planting areas approximately 8,5 million Ha. Indonesia is the biggest palm oil exporter for India by dominating $83 \%$ of palm oil market in 2010 . However, there was unfortunately a decrease of Indonesia palm oil export in 2014 to $60 \%$.

\footnotetext{
${ }^{1}$ Tim Penyusun Badan Pusat Statistik (BPS) Indonesia, Statistik Kelapa Sawit Indonesia 2014, Jakarta, 2015.
} 
A number of factors influence the decrease of market segment comprise the prevail of exit tax for palm oil and its related-products by Indonesian government which consequently has made the price of Indonesia palm oil in global market increase, including to India. Subsequently the decrease demand of Malaysia palm oil due to exil tax for Malaysia palm oil is lower thn Indonesia and there is an economic partnership between Malaysia and India through Malaysia-India Comprehensive Economic Cooperation (MICECA). Moreover, the industrial development of India's palm oil through Oil Palm Development Programme (OPDP) and National Mission Oil Seeds \& Oil Palm (NMOOP).

In the other hand, implication of the decrease of palm oil market segmentation is a considerably wide opportunity to boost export volume of palm oil to India. In addition, the tax potency which obtained from these exports will generally disappear and intrude the development of Indonesia palm oil industry. Indonesian government therefore has the interest to maintain its market segmentation to India. Hence, based on this background, the author will analyze the strategy of Indonesian government to maintain the palm oil market to India.

\section{LITERATURE REVIEW}

Based on literature review, there are a number of the previous researches regarding with this topic. Ira Kristina Br. Lumbantobing in their research entitled “Identifikasi Faktor Sukses Kunci Strategi Memasuki Pasar India Bagi Produk Minyak Goreng Kelapa Sawit dari Indonesia Dengan Analisis PEST (Politik, Ekonomi, Sosial dan TeknologiI)" "2 revealed that to undertake the strategy to enter India market, Indonesia palm oil producer have utterly the potency to enter where the market is more open than before. The producers entail to buid the partnership (networking) with local producers. Hence, supporting factors can hopefully be intensive, such as communication line, distribution line, and marketing resources to bolster the strategy to enter India market.

In addition, a journal written by bambang Drajat and hamzah Bustomi entitles "Alternatif Strategi Pengembangan Ekspor Minyak Sawit Indonesia" by using Analytical Hierarchy Proscess (AHP) method. It states that palm oil development strategy concerning with competitiveness comprise: resources optimalization, institution improvement, and

\footnotetext{
${ }^{2}$ Ira Kristina Br. Lumbantobing, Identifikasi Faktor Sukses Kunci Strategi Memasuki Pasar India Bagi Produk Minyak Goreng Kelapa Sawit dari Indonesia Dengan Analisis PEST (Politik, Ekonomi, Sosial dan Teknologi), Fakultas Ekonomika dan Bisnis (UGM), Yogyakarta, 2014.

${ }^{3}$ Bambang Drajat dan Hamzah Bustomi, Alternatif Strategi Pengembangan Ekspor Minyak Sawit Indonesia, Jurnal Manajemen \& Agribisnis, vol 6 No. 1 Maret 2009.
} 
policy implementation. Herein, the actors involved consist of government, State OwnedEnterprises, private and cooperative enterprise/Small and Medium Enterprises.

Moreover, paper written by The Ministry of Trade entitled Analisis Kebijakan Bea Keluar (BK) CPO dan produk turunanannya ${ }^{4}$ scrutinize that the impact of The Regulation from Misnitry of Finance No. 67/PMK.011/2010 about the exit tax for Crude Palm Oil $(\mathrm{CPO})$ and its related products is aimed to manage excessive $\mathrm{CPO}$ export which is intrusive to domestic oil needs. Furthermore, it is aimed to boost Indonesia palm oil industry. In contrast, this policy decreases Indonesia export value to main importer countries, such as India, Netherland, Germany, Italy, and Singapore.

Andi Alatas asserted in his research "Trend Produksi dan Eksport Minyak Sawit (CPO) Indonesia"5 that palm oil production trend averagely experience the rise. Furthermore, production value trend, export volume trend, and export value trend of Indonesia palm oil also experience the increase from year to year. The factors generally influence export to India are palm oil international price, Rupiah exchange rate, percapita income, population, and substitution price.

Tuti Ernawati and Yeni Septia in journal entitles Kinerja Ekspor Minyak Kelapa Sawit Indonesia ${ }^{6}$ stated that Revealed Comparative Advantage (RCA) of CPO export and Indonesia PKO is lower than Malaysia and Thailand, but similarly with Colombia. Analysis of Constant Market Share (CMS) of Indonesian CPO and PKO tend to decrease comparing with the growth of global export.

A number of literatures above were analyzed using one or several similar variables either economy or politic. Therefore, in this research the author will examine the challenges and obstacles of this issue by using the international political economy paradigm with focusing on several dissimilar variables yet still substantial correlated. Hence, the government as economic driving force has substantially roles in boosting the oil industry in Indonesia, but keep enforcing the partnership with private sector. The competitiveness improvement is the pivotal key of Indonesian palm oil industry to maintain its market in India.

\footnotetext{
4. Analisis Kebijakan Bea Keluar (BK) CPO dan produk turunanannya. Diterbitkan oleh Badan Pengkajian dan Pengembangan Kebijakan Perdagangan, Pusat Kebijakan Perdagangan Luar Negeri, Kementrian Perdagangan, Jakarta. 2013

5 Andi Alatas, Trend Produksi Dan Eksport Minyak Sawit (CPO) Indonesia, tesis pascasarjana studi manajemen agribisnis UGM, Yogyakarta, 2015.

6 Tuti Ermawati dan Yeni Saptia, "Kinerja Ekspor Minyak Kelapa Sawit Indonesia”, dalam Buletin Ilmiah Litbang Perdagangan, Vol 7. No 2, Desember 2013.
} 


\section{RESEARCH METHODS}

\section{Competitive Advantage Theory of Berlian Model from Michael Porter}

The competitiveness simply can be used to determine the position of a commodity in competitive market. According to Martin et all, one of competitiveness indicator is market segmentation. ${ }^{7}$ If market segmentation of commodity increase, it means that we can generally harness the market segmentation approach and the growth of market. Competitiveness is the ability of producer to produce a commodity with low-cost that production activity can be profitable in international market level price.

Competitive advantage theory with international competitiveness berlian model revealed by Michael Porter in his book "The Competitive Advantage of Nation" explains about national competitive advantage aspect until the forming and developing competitive industry. Based on Porter model, we can analyze the competitive development of Indonesia palm oil shown as below.

1. The condition of production factor comprises farmer skills, farming areal and palm oil location, soil quality, climate, etc.

2. Demand condition (domestic and international)

3. Related-industry and other supporting factors (transportation service in distribution, banking system, promotion, etc)

4. Strategy, structure, and competition

5. Opportunity, for example there is dramatic exchange rate currency changes this year make palm oil price cheaper that can provide the profit if palm oil exported.

6. Government (central and regional), through moneter policy, finance, and trade.

\section{Developmental State}

Developmental state is usually concerning with development model which applied in East Asian countries. It explains that development model of a state focus on state capacity buiding which needs institutional relations supporting each other. This concept was introduced firstly by Cahlmers Johnson through his book "MITI and The Japanese Miracle: The Growth Industrial Policyl 1925-1975”. He depicted the broad government roles by providing the insentive for business community through administrative regulations,

\footnotetext{
${ }^{7}$ Martin, L. Westgren dan Van Duren, E. Agribusiness Competitiveness Across National Boundaries, dalam American Journal of Agricultural Economics, bulan Desember 1991. Hal 1456-1464.
} 
subsidies, protections, and market survey ${ }^{8}$. Johnson asserted that development state should be understood by 3 main characteristic, consist of ${ }^{9}$ :

1. The big roles of government in economic development sector

2. The priority of major policy for economic growth

3. The main agent of development in state birocracy comprises people with the best managerial skills in birocracy that enable them to take the initiative and work effectively.

In analyzing the strategy of Indonesian government to maintain their market segmentation in India, we can examine that the relations between government and private sector with public-private innovation alliance varian is to create the ecosystem that can support palm oil industrial sector to hold on in India's market by creating the strategic policy. The roles of government in this strategy seems pivotal where their authority through policy and regulation. The private sector however plays the important roles as well. Government agents in this strategy consist of Ministry of Agriculture, particularly Directorate of Holticuture, Ministry of Finance, Ministry of Trade, Ministry of Industry and Coordinator Ministry of Economy, and National Development Planning Agency.

\section{RESULTS AND DISCUSSION}

The common thread of the cause decline market share of Indonesia palm oil in India is competitiveness. Malaysia has a higher competitiveness than Indonesia so normal that India increase their purchases to Malaysia. India saw the condition of Indonesia palm oil industry which incidentally is largest exporter in the world today could be pusued, at least can be applied in India. Needed to increase competitiveness of Indonesia palm oil products to maintain market share of Indonesia palm oil in India.

Economic cooperation between two countries about new renewable energy ${ }^{10}$ though not as big as palm oil trade. It also shwos the economic cooperation between Indonesia-India like cooperation Malaysia-India not will happen in near future. So that Indonesia government's effot to focus on increasing competitiveness among Research and Development (R\&D) of palm oil, promotion and improvement of service and trading facilities palm oil industry. Concrete forms of these efforts include:

\footnotetext{
${ }^{8}$ Chalemers Johnson, MITI and Japanese Miracle: The Growth Industrial Policy 1925-1975, Stranford University Press, Standfor, 1982, hal 307

${ }^{9}$ Ibid

10 Indonesia dan India jalin kerja sama energi terbarukan dan kebudayaan dalam http://www.republika.co.id/berita/nasional/umum/15/11/02/nx6ejs335-indonesiaindia-jalin-kerja-samaenergi-terbarukan-dan-kebudayaan diakses pada 18 Mei 2016.
} 


\section{A. Crude Palm Oil (CPO) Supporting Fund (CSF)}

Crude Palm Oil (CPO) Supporting Fund (CSF) is a levy on export of Crude Palm Oil (CPO) and its derivatives. CSF was established pursuant to Presiddential Decree (Decree) No. 61 year 2015 concerning the fund of collection and use of palm Oil on 18 May 2015. The proceeds are not entered into the state budget (APBN). CSF fund managed by The Fund Management Board, which was established by Treasury through The Ministry Finance regulation No.13/PMK.01/2015 dated 11 June 2015. The use of CSF fund to encourage development of sustainable palm oil. The funds collected are used for the benefit as follows:

1. Development of Human Resources (HR) oil palm plantation.

2. Research and Development of oil palm plantation. In 2015 ago has disbursed Rp 62 bilion to support 46 research.

3. Facilities and infrastructure for oil palm plantations. Subsudies replating of oil palm plantations to small farmers through cooperatives amounting to $\mathrm{Rp} 25$ million per hectare.

4. Subsidies Biofuel increased mandatory biodiesel from $10 \%$ to $15 \%$ applied by the government through B15. Price biofuel biodiesel is more expensive than the price of diesel with difference $\mathrm{Rp}$ 1000/liter and to cover difference is taken from contribution $\mathrm{CSF}^{11}$. In 2015, no budget from the state budget to subsidize biofuel biodiesel.

\section{B. Indonesia Trade Promotion Center (ITPC) Chennai, India}

Indonesia Trade Promotion Center (ITPC) Chennai was established in 2011. The main task of ITPC is promoting exports, facilitating business meeting, market studies, organizing trade fairs remain in ITPC and help Indonesia businesses to follow international trade fairs, trade information service, organizing a trade mission to Indonesia, make regular visit to companies/market and market inteligenci as well as other tasks ${ }^{12}$. The exhibition followed and held ITPC Chennai is:

1. Aahar International Food \& Hospitality 31 th, $15-19$ March $2016^{13}$

\footnotetext{
${ }^{11}$ Rafika Sari, Rencana kebijakan Crude Palm Oil Supporting Fund, Info Singkat Ekonomi dan Kebijakan Publik Vol.VII, 07/I/P3DI/April/2015, Jakarta, 2015.

12 ITPC dalam http://eximjatim.com/index.php?option=com_ckforms\&view=ckformsdata\&layout $=$ data\&id $=$ f3\&controller $=$ ckdata\&Itemid $=64$ diakses pada 25 April $201 \overline{6}$.

1331 st Aahar International Food \& Hospitality Fair 2016 dalam http://itpcchennai.com/member/31st-aaharinternational-food-hospitality-fair-2016-2/ diakses pada 18 Mei 2016.
} 
Is one of the largest exhibitions in south asia with an area of 45 thousand square meters. Foliowed by 872 participants from 22 countries with an averange of 44.650 visitorss. Attended by foreign business delegation from United States, Europe Union, Singapore, Bangladesh, Nepal and others. Then the representatives of foreign companies fom australia, Afganistan, Canada, Denmar, Germany, Japan, South Korea, Poland, Saudi Arabia, Turkey, and others. With 98\% satisfaction rate of participants to participate in next exhibitation.

2. Remark ndonesia EXPO $2015^{14}$

A trade show created by the Indonesia embassy in India and ITPC Chennai to promote various products Indonesia to India. The exhibition was held in Chennai on 19-21 June 2015.

\section{Palm Oil Industrial Cluster (KIKS)}

Palm oil industrial is a concrete action of The Masterpaln for Acceleration and Expansion of Indonesia Economic Development (MP3EI). Vision of MP3E1 is to make Indonesia into developed contries and including ten major countries in the world by 2025. The main contribution to the improvement of industrial clusters is not a purely economic scale, but rather on creation of solutions to externalities factors, such a ecology, infrastructure and other factor external that are usually not handle properly in developing countries due to failure of coordination. Based on experience of industrial clusters in developed countries, increased competitiveness can be done through locally based organizations effeciency of quality, design, speed of innovation and speed of response. According Cheney, the benefits that be can be gained from development of clusters is ${ }^{15}$ :

1. The atmosphere of competition between certain compenies in the cluster will spread and lead to competition between other companies in cluster that spurred accretion diversify new products.

2. Newcomers in cluster cause increased (upgrading).

3. Information flows freely and spread rapidly.

4. Interconnection within cluster generates new ways to compete and new opportunities for diversification.

\footnotetext{
${ }^{14}$ Remarkable Indonesia EXPO 2015 dalam http://itpcchennai.com/member/remarkable-indonesia-expo-2015/ diakses pada 18 Mei 2016.

${ }^{15}$ Cheney, Policy Lessons from Trade Focussed, Two Sector models, Journals of Policy Modeling, 12 (4), 2002. Hal 625-657
} 
5. Cluster will encourage growth and play a role in the stimulation of differention and help to overcome attitude that only focuses inward, not flexible and fast attitude are satisfied with what has been achieved, which is characteristic of companies that were nearing the end of its growth curve (naturing industries).

Clustering is applied to the palm oil industry in Indonesia basically want to improve competitiveness and increase value of palm oil production. It is a concern in conctruction of the Palm Oil Industrial Cluster (KIKS) beginning with commitment of central and local government, and then look at the factors that both industrial and nfrastructure (roads, ports, etc) as well as public facilities. The determination of palm oil industrial cluster have some consideration. Some of the factorss include is availability of land, conditions, position of location of raw materials, ports and other infrastructure as well as regulation and incentives provided by local government. However, these requirement are not rigid due to different locations depending supporting factors and limaitations. Here are some of the locations designated as palm oil industrial clusters, is:

a. Sei Mangkei (North Sumatra)

Sei mangkei administratively located in Simalungun regency, North Sumatra province, but is fuctional in the area of oil palm plantation owned by PT. Perkebunan Nusantara III (PTPN III). Developed land area of 2002 Hectare.

b. Dumai (Riau)

Dumai is a municipality in the province of Riau. Land development of palm oil industrial cluster located in Bukit Kapur district with total area of 15,433 hectares, village of Lubuk Echoes of the spacious 2100 hectares and Basilam village with an area of 132 hectares.

c. Maloy (East Kalimantan)

Maloy is located in East Kutai regency, East Kalimantan province. The total area of the region in Maloy is 577 hectares. 


\section{CONCLUSION}

Effort by the Indonesia government has not felt significant because it is relatively new, or in refinement stage. CSF came into force in May 2015 in the first year the new enactment provides support short term research and subsidies given to oil palm replating still touches a small part of farmrs. The limited budget and have not socialized widely constraint. Indonesia Trade Promotion Center (ITPC) Chennai executed based on the amount of funds received from state or private voluntary donations. So make a plan that is implemented in accordance with existing funds. Palm Oil Industrial Cluster (KIKS) in Sei Mangkei was inagurated by president jokowi in 2015 is not yet operating optimally. KIKS Dumai and Maloy in refinement stage. KIKS Maloy is planned to start operating in 2018.

Result of this research is the strategy of Indonesia government maintanins palm oil market in India through three steps above demonstrate positive impact. Although some parts are not running perfectly. The government as a stimulant to increase competitiveness of Indonesia palm oil is felt has done its job as it should. Government agencies directly involved in this strategy also provides maximum performance. In the future this strategy can be continued with evaluation of continuous improvement considering Malaysia as a major competitor of Indonesia palm oil exporters to India also has a strategy to continue to improve their competitiveness to take on position of Indonesia as the largest exporter of palm oil to India.

\section{REFERENCES}

31 st Aahar International Food \& Hospitality Fair 2016 in http://itpcchennai.com/member/31 st-aahar-international-food-hospitality-fair-20162/ accessed on 18 May 2016.

Analisis Kebijakan Bea Keluar (BK) CPO dan produk turunanannya. published by Badan Pengkajian dan Pengembangan Kebijakan Perdagangan, Pusat Kebijakan Perdagangan Luar Negeri, Kementrian Perdagangan, Jakarta. 2013.

Andi Alatas, Trend Produksi Dan Eksport Minyak Sawit (CPO) Indonesia, thesis postgraduate agribusiness management sudies UGM, Yogyakarta, 2015.

Bambang Drajat dan Hamzah Bustomi, Alternatif Strategi Pengembangan Ekspor Minyak Sawit Indonesia, Jurnal Manajemen \& Agribisnis, vol 6 No. 1 March 2009.

Chalemers Johnson, MITI and Japanese Miracle: The Growth Industrial Policy 1925-1975, Stranford University Press, Standfor, 1982. 
Cheney, Policy Lessons from Trade Focussed, Two Sector models, Journals of Policy Modeling, 12 (4), 2002.

Indonesia dan India jalin kerja sama energi terbarukan dan kebudayaan in http://www.republika.co.id/berita/nasional/umum/15/11/02/nx6ejs335indonesiaindia-jalin-kerja-sama-energi-terbarukan-dan-kebudayaan accessed on 18 May 2016.

Ira Kristina Br. Lumbantobing, Identifikasi Faktor Sukses Kunci Strategi Memasuki Pasar India Bagi Produk Minyak Goreng Kelapa Sawit dari Indonesia Dengan Analisis PEST (Politik, Ekonomi, Sosial dan Teknologi), Fakultas Ekonomika dan Bisnis (UGM), Yogyakarta, 2014.

ITPC in http://eximjatim.com/index.php?option=com_ckforms\&view=ckformsdata\&layout $=$ data\&id $=\mathrm{f} 3 \&$ controller $=$ ckdata\&Itemid $=64$ accessed on 25 April 2016.

Martin, L. Westgren dan Van Duren, E. Agribusiness Competitiveness Across National Boundaries, dalam American Journal of Agricultural Economics, bulan Desember 1991.

Rafika Sari, Rencana kebijakan Crude Palm Oil Supporting Fund, Info Singkat Ekonomi dan Kebijakan Publik Vol.VII, 07/I/P3DI/April/2015, Jakarta, 2015.

Remarkable Indonesia EXPO 2015 in http://itpcchennai.com/member/remarkableindonesia-expo-2015/ accessed on 18 May 2016.

Drafting teamPenyusun Badan Pusat Statistik (BPS) Indonesia, Statistik Kelapa Sawit Indonesia 2014, Jakarta, 2015.

Tuti Ermawati dan Yeni Saptia, "Kinerja Ekspor Minyak Kelapa Sawit Indonesia", in Buletin Ilmiah Litbang Perdagangan, Vol 7. No 2, Desember 2013. 